\title{
Do Microwaves of Mobile Phone Affect the Testicular Tissue Structure? (A histopathological and ultrastructural study)
}

\author{
Samir A. Nassar \\ Department of Zoology, Faculty of Science, Zagazig University
}

\begin{abstract}
:
Background: Some studies have reported that microwave radiation have adverse effects on reproduction. Therefore, the purpose of this study was to investigate the possible effects of mobile phone microwaves on the histological structure and ultrastructure of mice testis.
\end{abstract}

Material: five adult male mice were subjected to the mobile phone microwaves (900- 1800 $\mathrm{MHz}$ ) for 30 days, one hour / day. Their exposure resulted in many histopathological and ultrastructural changes.

Results: The light microscopic examination of testis of irradiated animals revealed: disorganization of the germinal epithelia, the seminiferous tubules taking elliptical aspects with intratubular vacuolization, abnormal morphology of early and late spermatids, rupture of the boundary membrane of the seminiferous tubules, pyknotic germ cells, damaged and illdefined interstitial cells. The semithin sections demonstrated an increased incidence of Sertoli cells but they are detached from the basal membrane, the pachytene spermatocytes appeared with abnormal faint heterochromatin and abnormal shapes of rounded and elongated spermatids and spermatozoa.

The ultrastructural examination illustrated Sertoli cells with lobulated nuclei, ill-defined nucleoli and ruptured cell boundary. Pachytene spermatocytes appeared with low integrity and faint and dispersed chromatin material. Some of them were necrotic and others were apoptotic. Early (rounded) and late (elongated) spermatids appeared with vacuolated cytoplasm and deformed morphology. The interstitial cells of Leydig appeared smaller in size with more electron dense components, vacuolated cytoplasm, ruptured mitochondria and fragmented nuclei. Their neighbouring blood capillaries appeared congested with damaged lateral pericytes .

Conclusion: The results of this study showed that $1 \mathrm{~h} /$ day (30 consecutive days) exposure of 900-1800 MHz microwaves affected the histological structure of mice testis particularly the Leydig cells and recorded an apoptosis-inducing effect on the spermatogenic cells. Further investigations are required to confirm these findings and to clarify the mechanism of action of the applied microwave exposure on male reproductive organs, as well as to establish the biological significance of these observations. 


\section{Introduction:}

Public and scientific awareness of questions about cell phone safety have increased greatly in the last few years about the adverse health effects on humans exposed to microwave (MW) radiation emmitted from celular phones and base stations. The question of whether MW of these frequencies could cause reproductive or developmental effects is of public interest (Dasdage et al., 2003). The last authors investigated the whole body exposure of rats to microwaves emitted from a cell phone. They detected no differences between control and experimental groups in all the studied end points including the testicular histology. Forgacs et al. (2006) studied the effect of whole-body $1800 \quad \mathrm{MHz}$ GSM-like microwave exposure on the testicular histology in mice. They reported that no microwave exposure related histopathological alterations were found in testis. Eduardo et al. (2007) reported that the low intensity pulsed radiofrequency emitted by a conventional cellular telephone does not impair testicular function in adult rats.

On the other hand, other investigators (Ozguner et al., 2002 and Osman et al., 2006) recorded harmful effects of microwaves on several parameters in the testis. Ozguner et al. (2002) concluded that EMF stimulation resulted in Leydig cell proliferation, increase in testosterone level, testis weight but decreased germ cell population. Osman et al. (2006) recorded acute and adverse effects of electromagnetic radiation (EMR) on sperm motility. An effect which may lead to behavioral or structural changes of the male germ cells by the long term exposure. Therefore, a lot of laboratory and epidemiological studies should be carried out to investigate the effects of MW on the male germ cells.

\section{Material and methods:}

\section{Animals:}

Ten adult male mice weighing (30- $40 \mathrm{gm}$ ) were used for this study. They were caged and fed with standard pelleted food provided by the animal house. After aclimatization, they were categorized into 2 equal groups. Five of them served as controls. The other five were exposed individually in a special plastic cage to the microwaves of mobile phone (Model, Nokia 6210).

\section{Irradiation:}

Each animal of the experimental group was irradiated for $1 \mathrm{~h} /$ day for 30 consecutive days. The animal inside the exposure cage was put directly in close contact to the source of emission of the mobile phone which activated by other phone continuouly during the exposure time ( Fig. 1 ). The frequency of the microwave radiation was $900-1800 \mathrm{MHz}$ and. SAR was $0.92 \mathrm{w} / \mathrm{kg}$ (as provided by the phone specifications). After the end of the irradiation course, treated and control animals were euthanized dissected and the left testis was taken from all the studied animals to undergo further processing. 


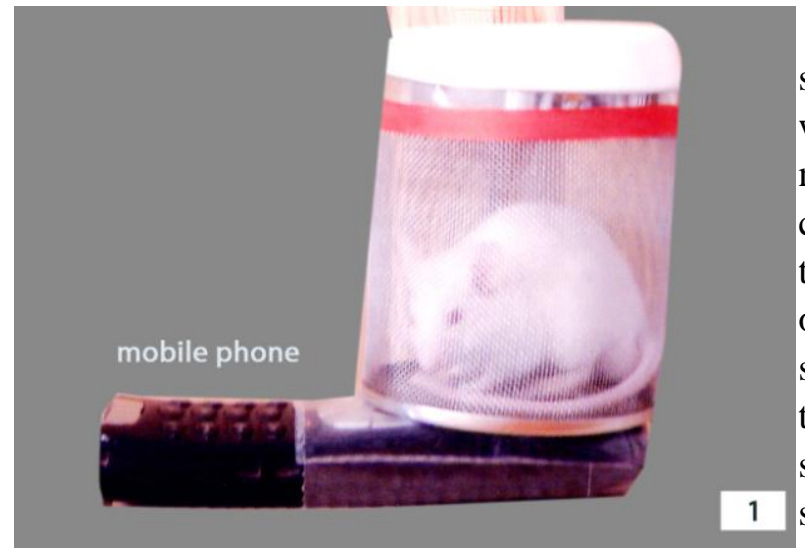

The LM examination of the tissue sections of testis of control animals stained with $\mathrm{H} \& \mathrm{E}$ (Fig. 2) illustrated clearly the normal organization of spermatogenic cells inside the seminiferous tubule of testis together with a normal presentation of interstitial cells of Leydig. The semithin section (Fig. 4) demonstrated more clearly the sequence and arrangement of these spermatogenic cells inside the

seminiferous tubule. Whereas the electron micrographs provided us with more cellular

Histopathological examination:

Tissue specimens of the testis were fixed in $10 \%$ neutral buffered formaline, dehydrated, cleared, sectioned at $3 \mu$ and stained with $\mathrm{H} \& \mathrm{E}$ for light microscopic examination (Bancroft and Gamble ,2002).

\section{Ultrastructural examination:}

Small pieces $(0.5 \mathrm{~mm})$ of testis from the animals of both groups were fixed immediately in $4 \%$ glutaraldehyde in $0.2 \mathrm{M}$ cacodylate buffer $(\mathrm{pH} 7.2)$ for $24 \mathrm{~h}$ at $4^{\circ} \mathrm{C}$. Specimens then post fixed in $1 \%$ $\mathrm{OsO}_{4}$ in cacodylate buffer and embedded in epon. Semithin sections were prepared and stained with toluidine blue for LM examination. Ultrathin sections were also prepared and stained with uranyle acetate and lead citrate for transmission EM examination (Jeol-JEM) at the EM unit, Ein Shams University.

\section{Results:}

The whole body exposure (900$1800 \mathrm{MHz}$ ) of adult mice to the MW of mobile phone produced negative effects in the testicular tissue structure at the level of the light and the electron microscopic studies.

In control animals: details for the elements of the testicular tissue described by figures 6, 7, 8, 9 and 10 .

\section{In irradiated animals:}

In comparison to the histological structure of testis of control animals, the light microscopic (LM) examination of testis stained with $\mathrm{H} \& \mathrm{E}$ of irradiated animals (Fig. 3) revealed several histopathological signs. The seminiferous tubules appeared elliptical with variable diameters and shapes. They contained intratubular vacuoles, abnormal shapes of rounded and elongated spermatids, pyknotic germ cells. They also appeared with ruptured tubular membranes and obvious depletion in the enclosed spermatogenic cells. Ill-defined and damaged interstitial cells were observed. The LM examination of the semithin sections (Fig. 5) illustrated more histopathological lesions such as detachment of Sertoli cells from the underlying membrane of seminiferous tubules. The incidence of these Sertoli cells was apparently increased where the study recorded more than one in a small microscopic area. Also, pachytene spermatocytes with faint chromatin and abnormal shapes of rounded and elongated spermatids could be observed. Intratubular vacuolization was evident inside the seminiferous tubules of the irradiated animals.

The EM examination of the tissue sections of testis of irradiated animals confirmed the previous observations and added more striking signs of pathogenesis. 
The Sertoli cells appeared with low integrity. One of them was necrotic and the other was apoptotic. Their nuclei appeared with pale and dispersed heterochromatin instead of the normal characteristic clumped form of chromatin (Fig. 11, 12). The rounded and elongated spermatids appeared with vacuolated cytoplasm and deformed morphology (Figs. 12, 13, 14) at all their stages of maturation. The interstitial cells of Leydig exhibited the most characteristic pathological sign observed in the present study (Figs. 15, 16, 17). They appeared

\section{Explanations of figures:}

Fig. (2): A section of testis of control mice ( $\mathrm{H} \&$ $E, x$ 400) showing the normal organization of spermatogenic cells of seminiferous tubules and normal presentation of interstitial cells (ic) of Leydig between the seminiferous tubules.

Fig. (3): A section of testis of irradiated animal (H \& E, x 400) showing a seminiferous tubule with elliptical shape containing abnormal shapes of rounded and elongated spermatids (rs, es) intratubular vacuoles (v), pyknotic germ cells (pg), depletion of spermatogenic cells $(\longrightarrow)$ and rupture of the tubular membrane (small $\uparrow$ ). Notice ill-defined and damaged interstitial cells (thick $\uparrow$ ). with low mitochondrial and lipoid content. Their mitochondria were severly damaged by the radiation exposure. Cytoplasmic vacuolization and nuclear fragmentation were also evident in these cells after irradiation. They also appeared more electron dense with poor cellular details than those of the control animals. All the cellular elements (Sertoli cells, spermatocytes, spermatids, sperms, Leydig cells) of the testicular tissue of irradiated animals appeared comparatively smaller than those of the control animals at the same magnification of the EM study.

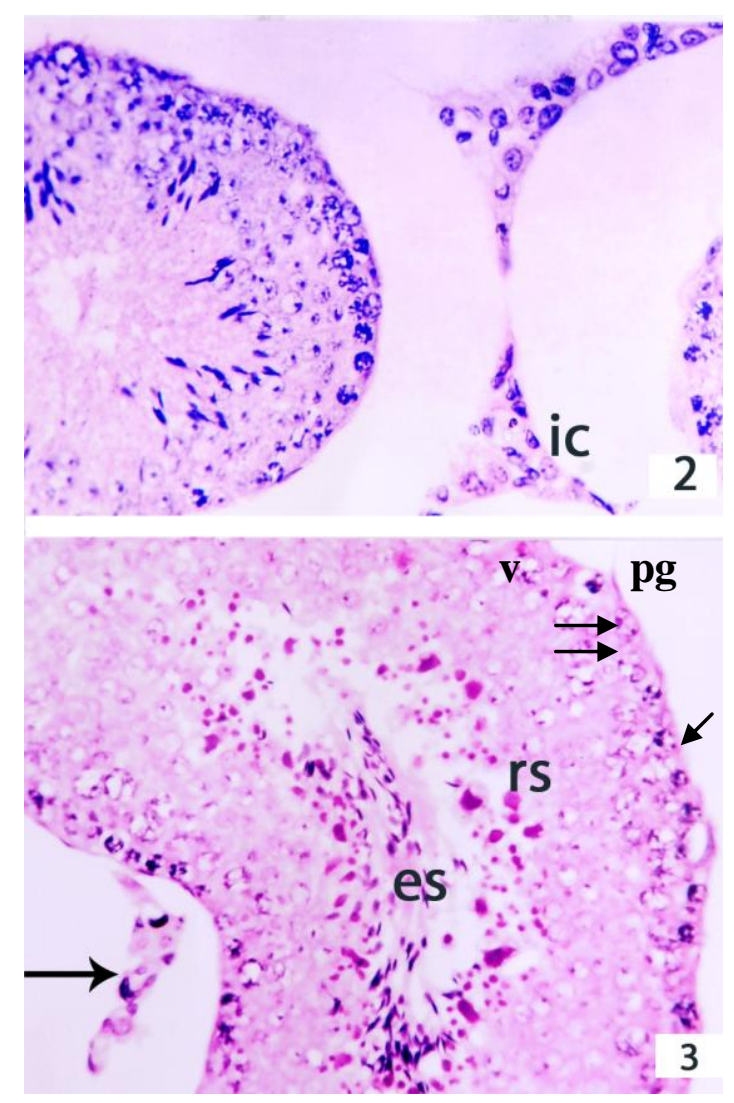


Fig. (4): Semithin section of testis of control animal stained with toluidine blue ( $\mathrm{x}$ 1000) showing the Sertoli cells (Sc), pachytene spermatocytes (Ps, rounded spermatids (rs), elongated spermatids (es) and spermatozoa (sp) in a normal pattern.

Fig. (5): Semithin section of testis of irradiated animal (Toluidine stain, $x$ 1000) showing three Sertoli cells (sc) one of them detached from the basement membrane, pachytene spermatocyte (ps) with faint chromatin, abnormal shapes of rounded and elongated spermatids (rs, es) and vacuolization (v).
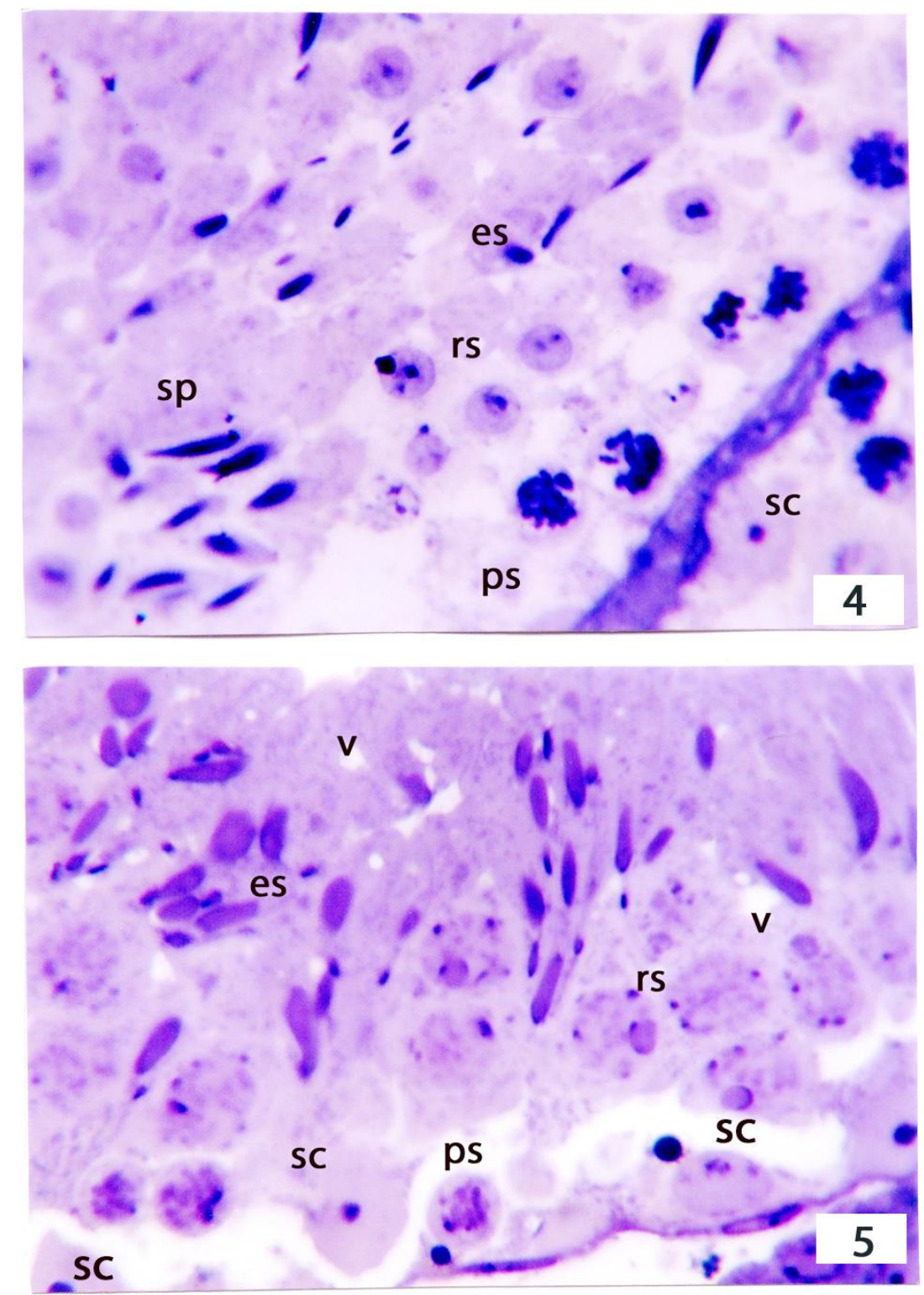
Do Microwaves of .....
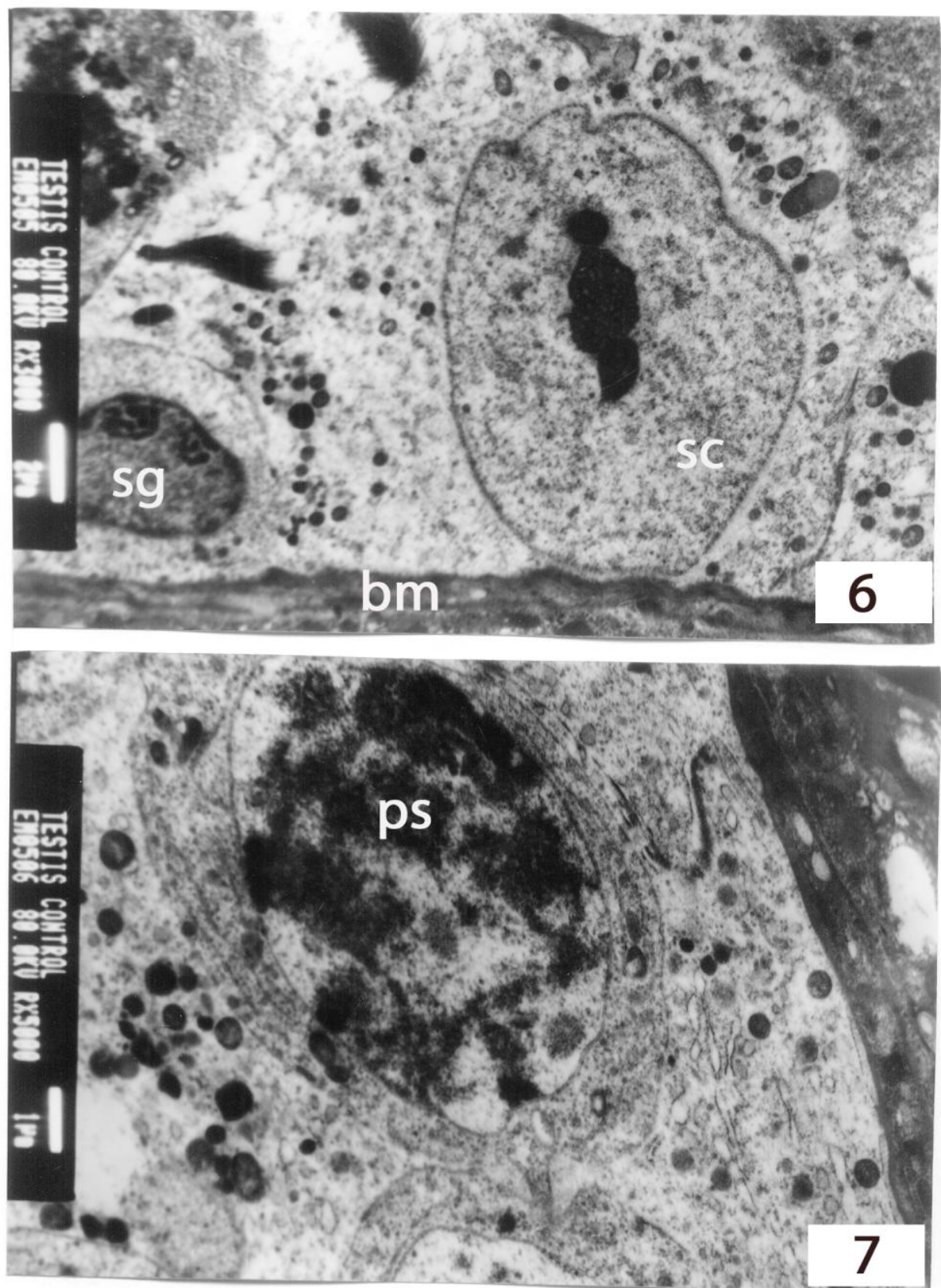

Fig. (6): EM in testis of control animal (x 3000) showing Sertoli cell (sc) with euchromatic nucleus (slightly indented) and having well defined nucleolus and cell membrane, voluminous cytoplasm, plenty of mitochondria. In the field a spermatogonium (sg) is present with pale cytoplasm.

Fig. (7): EM of testis of control animal (x 5000) showing pachytene spermatocyte with intact cell boundary and its characteristic clumped heterochromatin. 

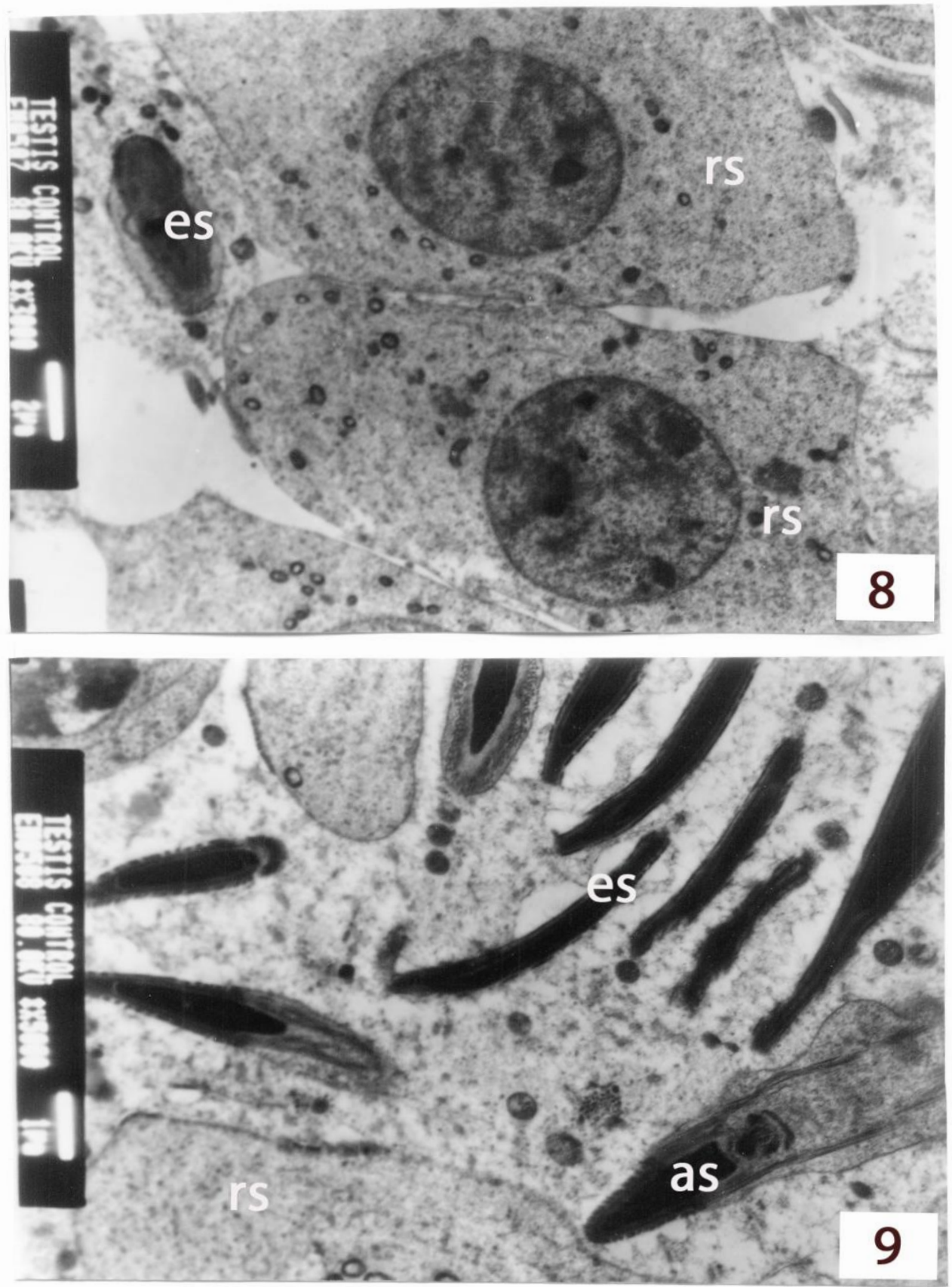

Fig. (8): EM of testis of control animal (x 3000) showing two round (early) spermatids (rs) with their characteristic ring from mitochondria and one elongated spermatid (es) with ovoid electron dense nucleus.

Fig. (9): EM of testis of control animal (x 5000) showing a collection of rounded and elongated spermatids (rs, es) at different stages of maturation, some having acrosomes (as). 
Do Microwaves of .....

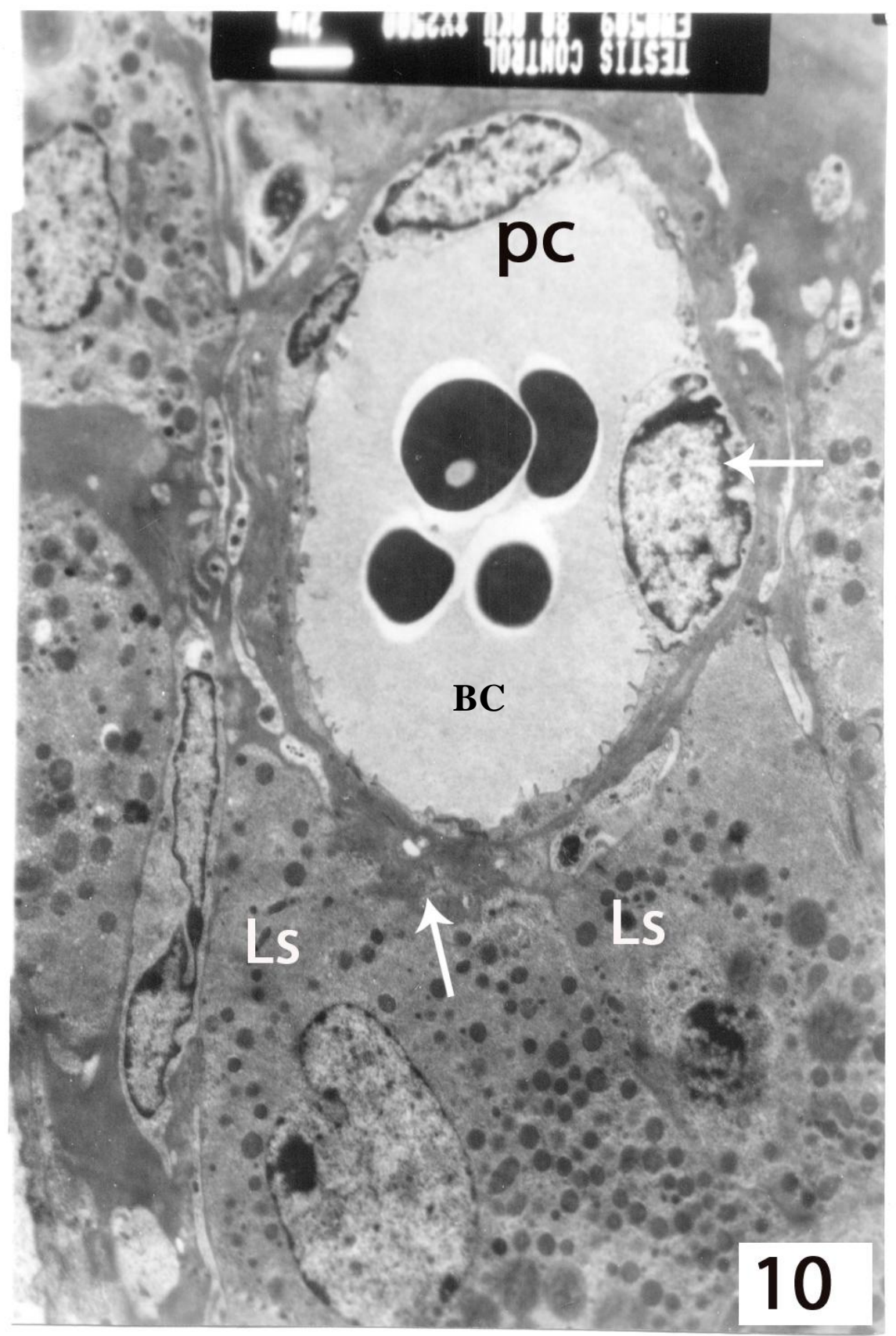

Fig. (10): EM of testis of control animal (x 2500) showing a typical Leydig cell (Ls) containing slightly indented nucleus, prominent nucleolus, abundant mitochondria and lipid droplets. At its top testosterone secretion is observed ( $\uparrow$ ) in its way to the blood capillary. The blood capillary $(\mathrm{BC})$ having lateral pericytes $(\mathrm{pc}, \leftarrow)$, RBCs and fenestrated wall. 

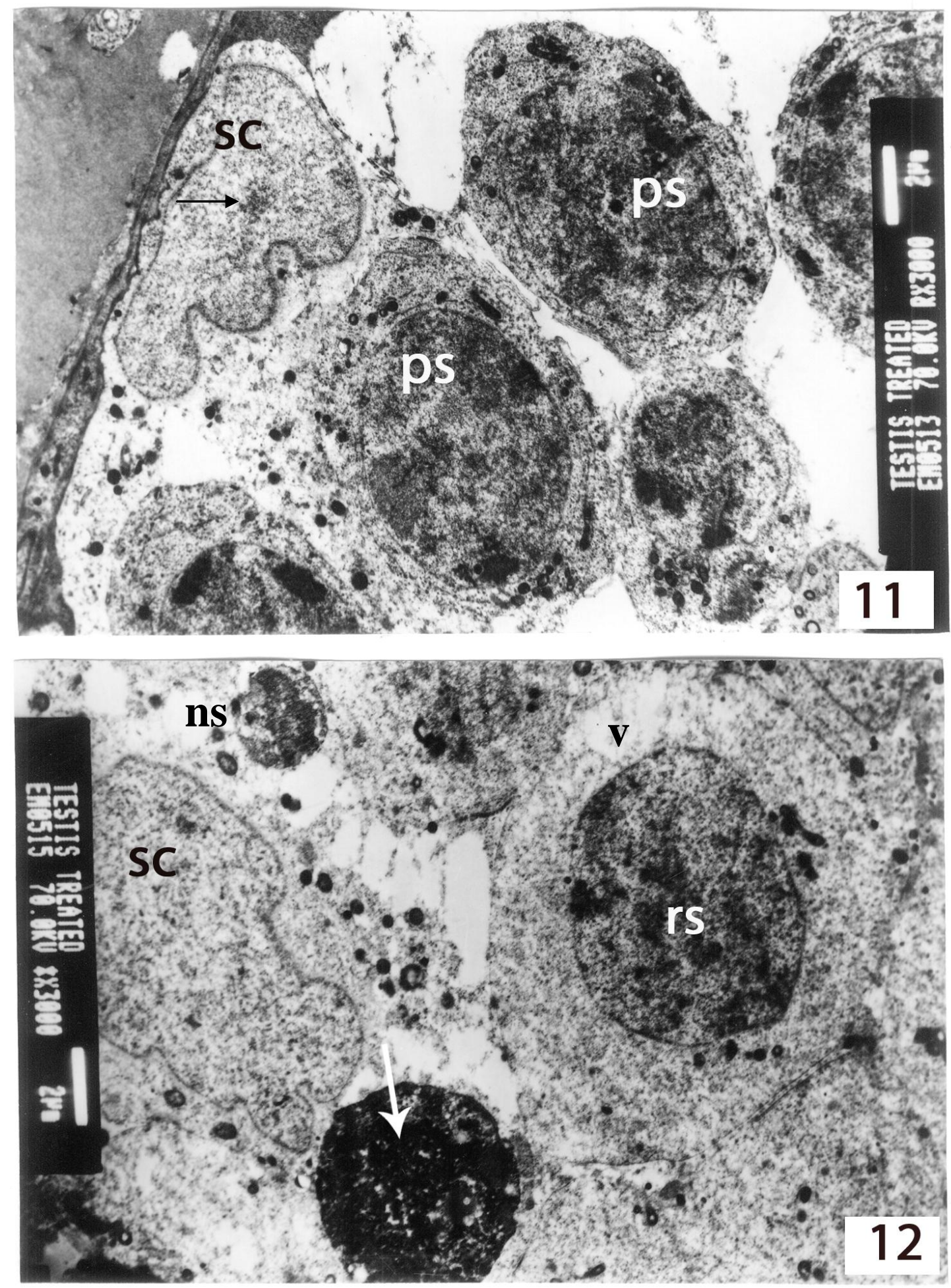

Figs. (11, 12): EM of testis of irradiated animal (x 3000) showing Sertoli cells (Sc) with lobulated nucleus, ill-defined nucleolus $(\leftarrow)$ and ruptured cell boundary. Also, pachytene spermatocyte (ps) with low integrity and faint and dispersed chromatin. Apoptotic spermatocyte $(\downarrow)$ and another necrotic one (ns) are present. A round spermatid (rs) with vacuolated cytoplasm (v) and more electron dense nucleus are also present. 

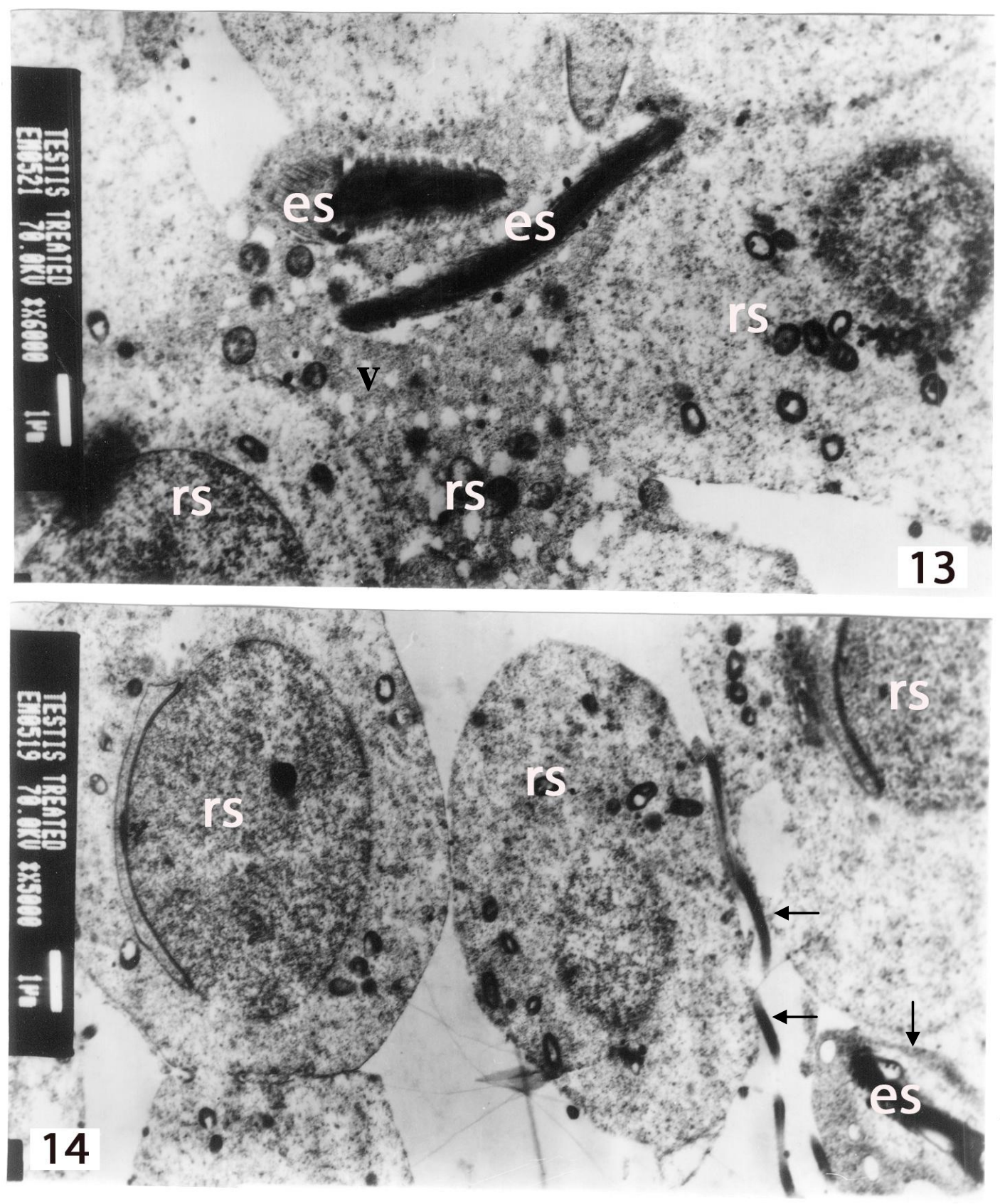

Figs. $(13,14)$ : EM of testis of irradiated animals (x 6000, x 5000 respectively) showing round and elongated spermatids (rs, es) at different stages of maturation. Some with vacuolated cytoplasm (v) others with deformed morphology $(\downarrow)$ and abnormal small sizes $(\leftarrow)$. 


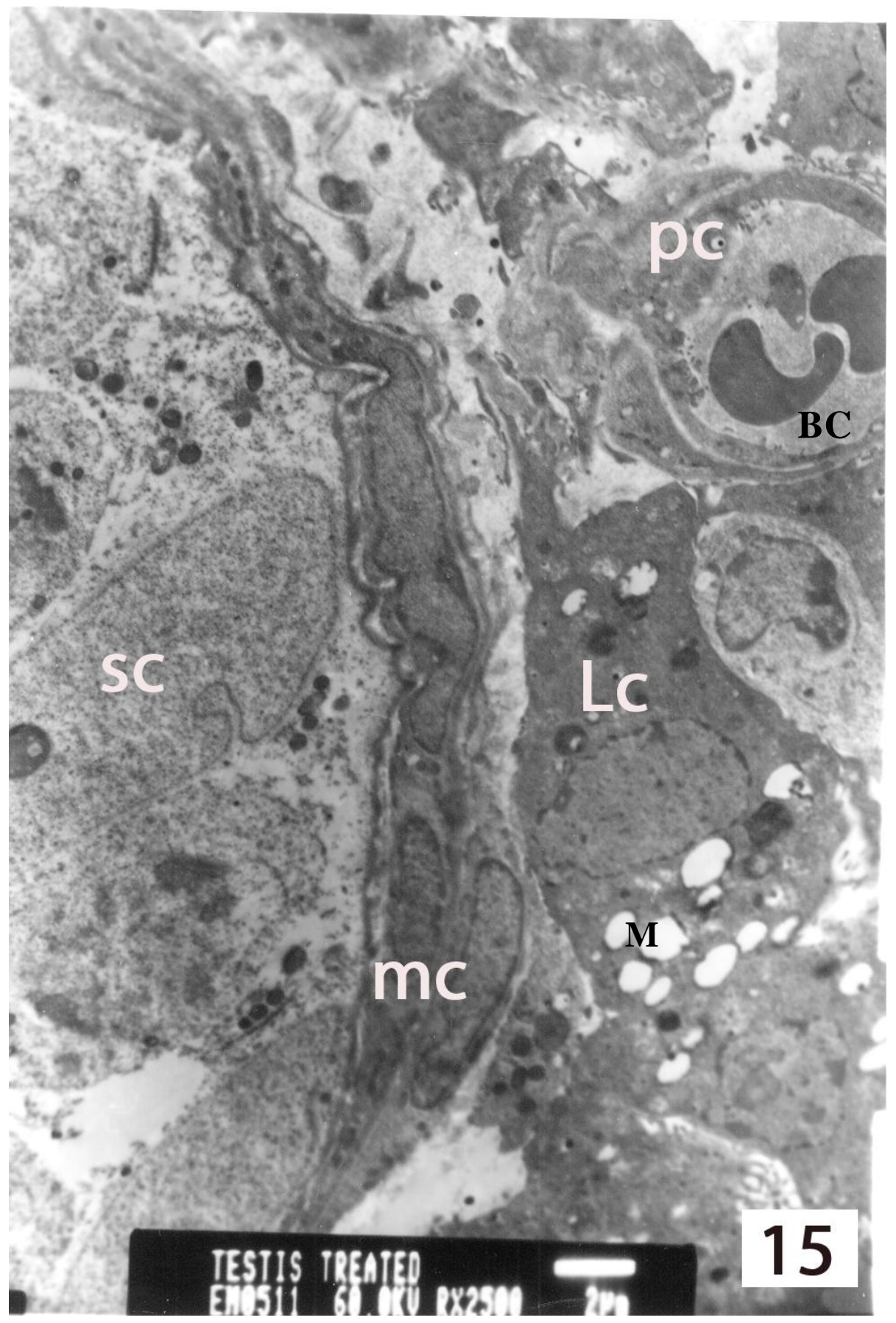

Fig. (15): EM of testis of irradiated animal (x 2500) showing a Leydig cell (Lc) with ruptured mitochondria (M). Their neighbouring blood capillary (BC) appeared congested and having a lateral damaged pericyte (pc). 

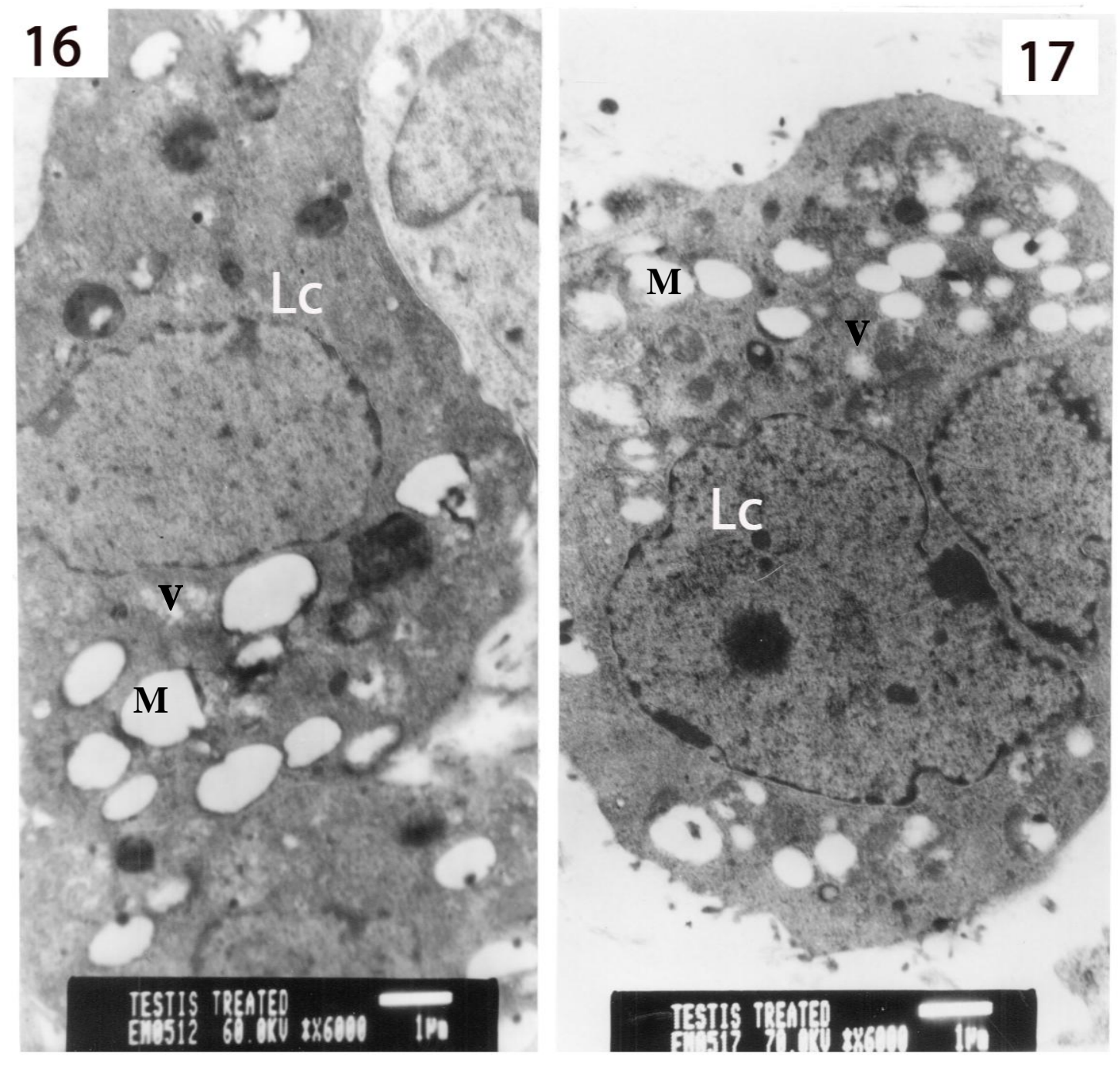

Fig. (16): Enlarged part of the last EM (x 6000) to illustrate clearly the paucity and rupture of mitochondria and vacuolated cytoplasm (v) in the Leydig cell (Lc).

Fig. (17): EM of testis of irradiated animal (x 6000) showing another Leyding cell (lc) with fragmented nucleus, ruptured mitochondria (M) and vacuolated cytoplasm (v). 


\section{Discussion:}

Thus in an answer to the question posed by the little of this paper I can say that microwave irradiation at a frequency of $900-1800 \mathrm{MHz}$ (SAR $0.92 \mathrm{w} / \mathrm{kg}$ ) for 30 consecutive days ( $1 \mathrm{~h} /$ day) affected the testicular tissue of mice. The major observations in the present study are discussed as follows:

The deformed morphology of rounded and elongated spermatids recorded in this study came in consistence with the previous observations of Bernabo et al. (2007). The authors recorded signs of morphological damage appeared in plasma membrane and at acrosomal level. They attributed this negative influence of extremely low frequency magnetic field (MF) on spermatozoa to an impairment in cell $\mathrm{Ca}^{2+}$ homeostasis and then dramatically affecting sperm morphology. It is possible to apply this explanation in the current study. Another explanation must be considered to interpret the present results. The magnetic field (MF) effect is not only directed against ion channels, but also the membrane physical structure can be affected by the MF exposure (Ho et al., 1996). The elliptical aspects of seminiferous tubules and the depletion in their content of spermatogenic cells which recorded in this study extend and confirm similar observations of Ozguner et al. (2002).

At the cellular level one of the most critical targets of microwave exposure in testicular tissue in the present study was the Leydig cell. These cells exhibited cytoplasmic vacuolization, rupture of mitochondria and poor cellular details. Other investigators (Moon et al., 2004) are in agreement with the present results. They recorded Leydig cell hyperplasia as a target for radiation exposure with concomitant increase in testosterone level. Other investigators
(Zeng et al., 2008) are in agreement with the present observations. They recorded dilatation in the endoplasmic reticulum, vacuolization in the Leydig cell and spermatogonia of rat testis after radiation exposure to electromagnetic pulses. But in contrast to the present observations other investigators

(Forgacs et al., 2006) suggesting that Leydig cells were not the primary targets of the applied microwave exposure or direct action of microwaves on Leydig cells was temporary only.

The vascular congestion of blood capillaries and the disorganization of germinal epithelia observed in this study as a result of radiation exposure support and confirm similar results of Nergidot et al. (1996). The current results which showed some necrotic and some apoptotic spermatocytes in the testicular tissue of irradiated animals led us to suggest an apoptosis-inducing effect for these microwaves on the spermatogenic cells. But this is in contrast to the observations of other investigators (Dasdag et al., 2008) who reported that mobile phone exposure does not induce apoptosis on spermatogenesis in rats.

The tissue effects resulting from MW exposure depends upon many factors such as the power density of the source, duration of exposure, frequency of radiation, composition of irradiated tissue and its ability to dissipate heat (Elder et al., 1989). Furthermore the mice is a poor model of man because its dimensions are much smaller, its scrotum is non-pendulus and its testis migrate freely through the inguinal canal between the abdomen and scrotum (Cairnie and Harding, 1981). However, as did many investigators, we accepted these differences and used the mice because of their ready availability and demonstrated utility of many kinds of biomedical research. However, difference 
in body size, geometry and physiological responses mean that extrapolation of these results to man is not straight forward and any such comparison should be made with great caution.

Conclusion: The results obtained from the present study showed some negative effects on the testicular tissue structure, but the mechanisms of the bioeffects needed to be confirmed in the future by further investigations.

\section{References:}

1. Bancroft J D and Gamble $M$ (2002): Theory and Practice of Histological Techniques, $5^{\text {th }}$ edition, Churchill, Livingstone, London.

2. Bernabò N, Tettamanti E, Pistilli $M G$, Nardinocchi D, Beradinelli P, Mattioli $M$ and Barboni $B$ (2007): Effects of $50 \mathrm{~Hz}$ extremely low frequency magnetic field on the morphology and function of boar spermatozoa capacitated in vitro. Theriogenology, 67: 801-815.

3. Cairnie $A B$ and Harding $R K$ (1981): Cytological studies in mouse testis irradiated with $2.45 \mathrm{GHz}$ continuous wave microwaves. Radiat. Res., 87: 100108.

4. Dasdag $S$, Akdag $M Z$ Z, Asken F, Yilmaz F, Bashan $M$ and Dasdag M M (2003): Whole body exposure of rats to microwaves emitted from a cell phone does not affect the testis. Bioelectromagnetics, 24: 182- 188.

5. Dasdag $S$, Akdag $M$ Z, Ulukaya E, Ulzunlar A K and Dilek L (2008): Mobile phone exposure does not induce apoptosis on spermatogenesis in rats. Archive. Med. Res., 39: 40-44.

6. Eduardo $P R$, Ernani L $R$, Marilise $M H$, Claudia $R$, Lucas $P L$ and Lucas $T$ (2007): Effects of subchronic exposure to radiofrequency from a conventional cellular telephone on testicular function in adult rats. J. Urology, 177: 395-399.
7. Elder J A, Czerski P A, Stuchly M A, Mild $K \quad H$, Sheppared $A \quad R \quad$ (1989): Radiofrequency radiation in: Sues $M J$ and Benwell-Morison D A, editors. NonIonizing Radiation Protection. $2^{\text {nd }}$ edition. Copenhagen: WHO. Pp. 117-173.

8. Forgacs Z, Somosy Z, Kubinyi G, Jozef B, Aranka H, Surjan A and Thuroczy $G$ (2006): Effect of whool- body $1800 \mathrm{MHz}$ GSM-like microwaves exposure on testicular steroidogenesis and histology in mice. Reproductive Toxicology, 22: 111117.

9. Ho MW, Haffegge J, Newton R, Zhow $Y$, Bloton S S, Ross, S (1996): Organism as polyphasic liquid crystals. Bioelectrochem Bioenergetic, 41: 81-91.

10. Moon KH, Shin HJ, Ahn H S, Kim J Y, Shin $S O$, Yun $S M$ and Hwang $Y D$ (2004): Long term exposure of rats to $2.45 \mathrm{GHz}$ electromagnetic field (Effects on reproductive function). IFMBE Proceeding 14(4): 2767-2769.

11. Nergidot Z Y, Akdag Caron Z, Ccedil Elidot $K S$, Ketanidot $M A$ and Dacedil D $S$ (1996): The effects of microwave radiation on morphology of rat testis. Progress in Biophysics and Molecular Biology, 65: 210.

12. Osman E, Emin O, Ibrahim Y, Tayfun $K$, Emin A, Gokahon K, Hasan C I, MehmetKemal I and Ahmet F P (2006): Effects of electromagnetic radiation from a cellular phone on human sperm motility: An in vitro study. Arch. Med. Res. 37: 840-843.

13. Ozguner I F, Dinar H, Yagmurlu A, Savas C, Gokcora I H and Yucesan S (2002): The effect of electromagnetic field on undescended testis after orhiopexy. Intern. Urol. Nephrol., 33: 8793.

14. Zeng L, Zou C, Zhang J, Wang XW, Ren D, Li Y, Guo G (2008): Effects of electromagnetic pulses on the rat testis. IFMBF Proceedings, 19: 461-465. 


\section{هل تؤثر الموجات الإثعاعية القصيرة للهاتف النقال على التركيب

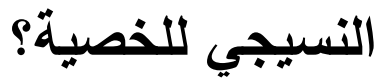

(دراسة هستوياثولوجية وتركيبية دقيقة)

\section{سمير عبد العظيم نصار}

قسم علم الحيوان - كلية العلوم - جامعة الزقازيق

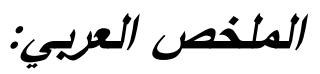

أثارت بعض الدراسات البحثية في الآونة الأخيرة بعض التساؤلات عن احتدال وجود تأثبرات

سلبية للموجات الإثعاعية القصيرة على جهاز الذكر التكاثري. ومن هنا جاءت فكرة الدراسة الحالية:

هل للموجات الإشعاعية ذات الطول الموجي القصبر آثارًا سلبية على التركيب النسيجي للخصية ؟

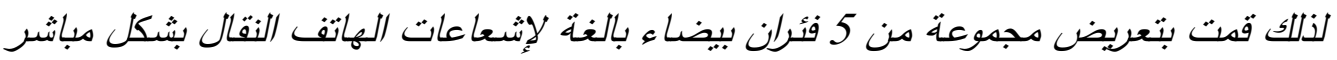

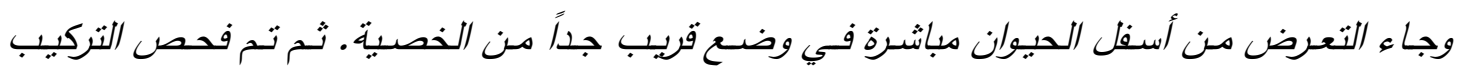
النسيجي للخصبة في المجموعة المشععة ومقازنته بالمجموعة النمطية الضابطة.

أسفرت النتائج عن وجود علامات هستوباثولوجية كثيرة بالدجهر الضوئي منها عدم انتظلام

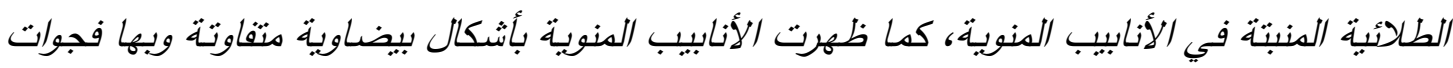

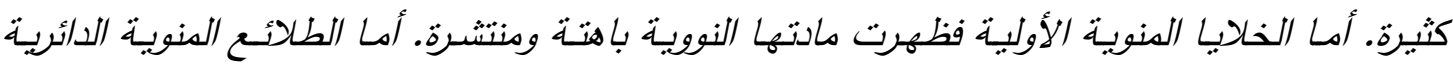
والمستطبلة فظهرث بأشكال غير طبيعية.

كما أسفرت النتائج عن تسجيل علامات باثولوجية أخرى بالمجهر الإلكترونسي النافذ منها خلايا سرتولي التي ظهرت بأنوبية مفصصنة ومتعرجة ونوبات فقبرة التعرف وأغشية خلوبية مهزقة وغير سلبية.

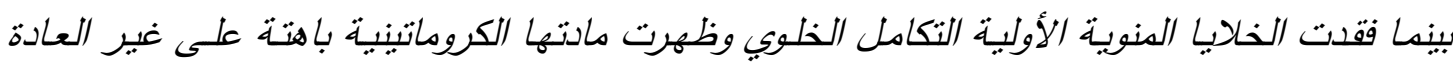

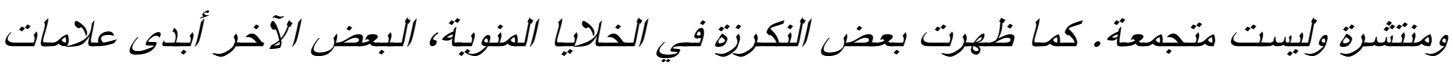

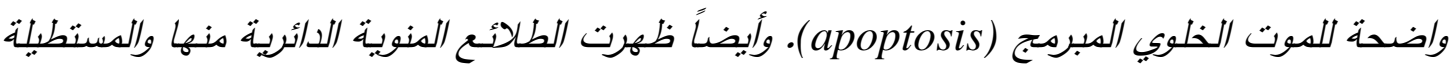
بأشكال ظاهرية غبر طبيعية ومشوهة وذات فجوات سبتوبلازمية. أما الخلايا البينية (Leydig cells) فأظهرت علامكات مرضية واضحة منها انفجار معظم الأجسام السبحية بداخلها وتفتت النواة وظهور

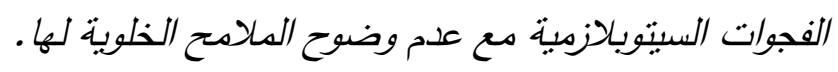

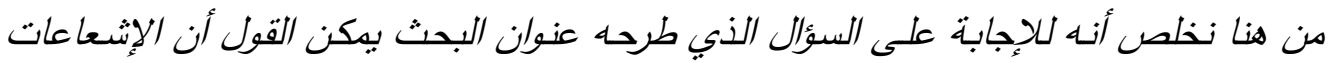

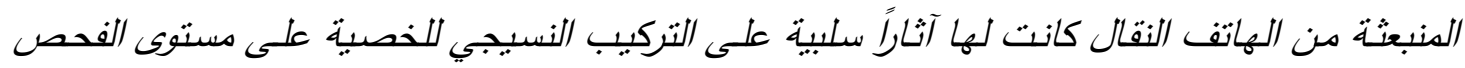

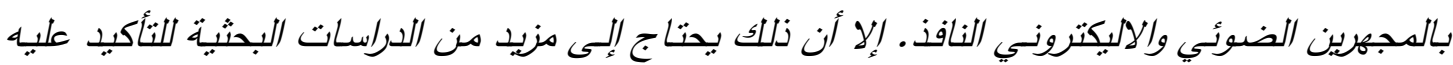

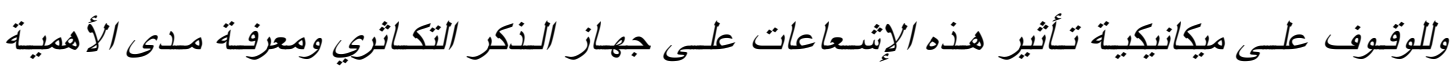
البيولوجية لهذه النتائج. 